\title{
Editorial
}

Theme Issue: Paul Myrdal Memorial Issue - Pharmaceutical Formulation and Aerosol Sciences

\section{In Memoriam: Dr. Paul B. Myrdal}

\author{
Philip J. Kuehl, ${ }^{1,2,5}$ Hugh D. Smyth, ${ }^{3}$ Stephen W. Stein, ${ }^{4}$ and Robert O. WilliamsIII ${ }^{3}$
}

\author{
Received 20 May 2019; accepted 21 May 2019; published online 3 June 2019
}

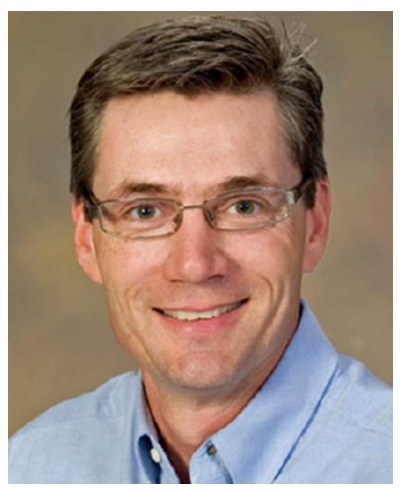

This theme issue is being dedicated to Paul B. Myrdal, Ph.D., who passed away on 19 May 2018. Paul's contribution to the science of inhalation drug development, solubility prediction, and service to the scientific community has touched the lives and careers of countless numbers of scientists. This theme issue brings together a collection of manuscripts that cover the breadth of the science Paul was involved in and the scientific careers of people he impacted.

Paul was born in Madison, Wisconsin where he grew and attended high school and the University of Wisconsin Madison. It was at the University of Wisconsin that Paul's future in sciences was set in course. This was in part due to meeting his future wife Kelly Jo Koch in freshman chemistry class. When Kelly moved to the University of Arizona in Tucson to complete her PharmD, she convinced Paul to reach out to a professor in the College of Pharmacy, Dr. Samuel Yalkowsky. Paul transferred to the

\section{Guest Editors: Philip J. Kuehl and Stephen W. Stein}

${ }^{1}$ LRRI, Albuquerque, New Mexico, USA.

${ }^{2}$ Lovelace Biomedical, Albuquerque, New Mexico, USA.

${ }^{3}$ The University of Texas at Austin, Austin, Texas, USA.

${ }^{4}$ M Drug Delivery Systems, St. Paul, Minnesota, USA.

${ }^{5}$ To whom correspondence should be addressed. (e-mail: pkuehl@lovelacebiomedical.org)
University of Arizona to complete his BS in Molecular and Cellular Biology in 1989 and joined the Yalkowsky graduate laboratory in Pharmaceutical Sciences. During his time in graduate school, Paul worked on several different programs that were all fundamentally tied to the science of solubility and the application of physical chemical properties to the calculation of aqueous solubility. These projects resulted in seminal publications of the Unified Physical Property Estimation Relationships (UPPER) and the Aqueous Functional Group Activity Coefficients (AQUAFAC) [1-7].

Dr. Myrdal left the University for a career at Minnesota Mining and Manufacturing Company (3M) in 1995. Over the course of the next 5 years, he worked on the preformulation and development of multiple different HFA-based metered dose inhaler programs. These included formulation development, scale up and transfer of manufacturing processes, and solid-state characterization of different drug substances. In addition, Paul worked on developing novel excipients suitable for use in HFA formulations and on inhalable lung cancer therapies using 5-lipoxygenase inhibitors and immune response modifiers [8,9]. As part of his work at 3M, Paul was awarded the coveted 3M's Technical Circle of Excellence in 1998 for his innovation in developing the manufacturing process for the world's first CFC-free steroid MDI, Qvar® (beclomethasone dipropionate HFA inhalation aerosol).

In 2000, Dr. Myrdal returned to Tucson to join the University of Arizona College of Pharmacy as an Assistant Professor in the same graduate program he graduated from. Paul built a well-regarded laboratory that provided scientific expertise in the area of inhalation formulation development and application to in vivo pharmacology and pharmacokinetic models. During his 18 years as a professor at the University of Arizona, Paul directly supervised 8 students that received their Ph.D.'s in Pharmaceutical Sciences and contributed to the graduate committees of more than $15 \mathrm{Ph} . \mathrm{D}$. graduates. These research projects built on Paul's expertise in the area of inhalation formulation development $[10,11]$; characterization of metered dose inhaler delivery [12, 13]; lung cancer, solubility prediction in aqueous media, and solubility measurement in HFA propellant systems [14]; and development of countless new characterization techniques. 
Over the course of Dr. Myrdal's career, he published over 50 peer-reviewed manuscripts, served on the editorial advisory board for Drug Development and Industrial Pharmacy, served as Editor for AAPS PharmSciTech, served as a guest editor for a highly cited theme edition focused on inhalation drug delivery in AAPS PharmSciTech, published multiple book chapters, and was a co-inventor on multiple patents. Throughout Paul's career, he received multiple awards as recognition of his valuable contributions to science. These included a Glaxo Post-Doctoral Fellowship, the $3 \mathrm{M}$ Non-Tenured Faculty award, and the University of Arizona Alumni Associate Extraordinary Faculty Award.

With all of Paul's accomplishments and contributions to science, the intangible contributions that Paul made to the lives of those he touched must be recognized. His ability to make a colleague or student pause and reconsider their conclusion or data touched many scientific careers. His ability to always have time to discuss a question (about science or life) over a beer at a conference will always be remembered and cherished by those who knew him. It is through these valuable contributions to science and the careers of so many peers that Paul's legacy will be remembered for years to come.

\section{ACKNOWLEDGMENTS}

The authors and editors of this theme edition would like to gratefully acknowledge all authors and co-authors who contributed their paper. We would also like to recognize all reviewers who assisted in reviewing the manuscripts.

\section{REFERENCES}

1. Myrdal PB, Manka A, Yalkowsky SH. AQUAFAC 3: aqueous functional group activity coefficients: applications to the estimation of aqueous solubility. Chemosphere. 1995;30:1619-37.
2. Myrdal P, Yalkowsky SH. A simple scheme for calculating aqueous solubility, vapor pressure and Henry's law constant: application to the chlorobenzenes. SAR QSAR Environ Res. 1994;2:17-28.

3. Yalkowsky SH, Myrdal PB, Dannenfelser R-M, Simamora P. UPPER II: calculation of physical properties of the chlorobenzenes. Chemosphere. 1994;28:1675-88.

4. Yalkowsky SH, Dannenfelser R-M, Myrdal PB, Simamora P, Mishra DS. Unified physical property estimation relationships (UPPER). Chemosphere. 1994;28:1657-73.

5. Yalkowsky SH, Krzyzaniak JF, Myrdal PB. Relationships between melting point and boiling point of organic compounds. Ind Eng Chem Res. 1994;33:1872-7.

6. Myrdal P, Ward GH, Simamora P, Yalkowsky SH. AQUAFAC: aqueous functional group activity coefficients. SAR QSAR Environ Res. 1993;1:55-61.

7. Myrdal P, Ward GH, Dannenfelser R-M, Mishra DS, Yalkowsky SH. AQUAFAC 1: aqueous functional group activity coefficients: application to hydrocarbons. Chemosphere. 1992:24:1047-61.

8. Stefely JS, Duan D, Myrdal P, Ross D, Schultz D, Leach C. Design and utility of a novel class of biocompatible excipients for HFA-based MDIs. Respir Drug Deliv VII. 2000;1:83-90.

9. Myrdal PB, Karlage K, Kuehl PJ, Angersbach BS, Merrill B, Wightman P. Effect of novel 5-lipoxygenase inhibitors on the incidence of pulmonary adenomas in the $\mathrm{A} / \mathrm{J}$ murine model when administered via nose-only inhalation. Carcinogenesis. 2007;28(5):957-61.

10. Myrdal PB, Sheth P, Stein SW. Advances in metered dose inhaler technologies: formulation development. AAPS PharmSciTech. 2014;15(2):434-55.

11. Gupta A, Stein SW, Myrdal PB. Balancing ethanol cosolvent concentration with product performance in 134a-based pressurized metered dose inhalers. J Aerosol Med. 2003;16(2):167-74.

12. Stein SW, Sheth P, Myrdal PB. Advances in metered dose inhaler technology: hardware development. AAPS PharmSciTech. 2014;15(2):362-38.

13. Stein S, Myrdal P. A theoretical and experimental analysis of formulation and device parameters affecting solution MDI size distributions. J Pharm Sci. 2014;93:2158-75.

14. Gupta A, Myrdal PB. Novel method for the determination of solubility in aerosol propellants. J Pharm Sci. 2004;93(10):2411-9.

Publisher's Note Springer Nature remains neutral with regard to jurisdictional claims in published maps and institutional affiliations. 